\title{
Lytic and inhibition responses to bacteriophages among marine bacteria, with special reference to the origin of phage-host systems
}

\author{
K. Moebus \\ Biologische Anstalt Helgoland (Meeresstation); \\ D-2192 Helgoland, Federal Republic of Germany
}

\begin{abstract}
The results of phage-host cross-reaction tests reported by Moebus \& Nattkemper (1981) were re-examined using serially diluted bacteriophage suspensions to elicit the actual type of reaction between the bacteria and phage lysates tested. More than 1450 phage-host systems were studied at $25^{\circ} \mathrm{C}$ incubation temperature. Among the nearly 300 phage strains used, 29 were identified as temperate ones. In about $65 \%$ of the phage-host systems bacteriophage propagation was indicated by plaque formation. The remaining systems were characterized by the "inhibition" reaction of bacteria to phage lysates indicated by homogeneously reduced bacterial growth within the test area without production of progeny phages. Since crude phage lysates had to be used, it remains obscure whether agents other than infective phage particles (defective ones or bacteriocins) caused this reaction. Among 269 systems of the inhibition type which were also tested at $5^{\circ}$ and $15^{\circ} \mathrm{C}, 54$ were observed to propagate phages at one of or both the lower temperatures. Plaques produced at $15{ }^{\circ} \mathrm{C}$ with several phage-host systems were found to yield only few progeny phages which generally could not be propagated to produce high-titer phage stocks. With one system temperature-sensitive phage mutants were isolated. The probability of inhibition reactions occurring was found to be higher with phage-host systems isolated east of the Azores than with systems derived from the western Atlantic. With systems from the last mentioned area the proportion of inhibition versus lytic responses of bacteria to phages was observed to increase with the distance between the stations where both parts of the systems were derived. The latter findings are discussed in view of the assumption that bacterial and bacteriophage populations undergo genetic changes while being transported from west to east.
\end{abstract}

\section{INTRODUCTION}

Recently, Moebus \& Nattkemper (1981) presented the findings of phage-host crossreaction (PHCR) tests performed with 774 bacterial and 298 bacteriophage strains isolated from water samples collected from the Atlantic Ocean between the European continental shelf and the Sargasso Sea as well as from the North Sea near Helgoland. In contrast to the methods usually employed for phage typing (Kasatiya \& Nicolle, 1974), only undiluted phage lysates were used for the PHCR tests to facilitate handling of the extensive material. For this reason the actual type of reaction of many bacteria to phages remained unknown.

There are two types of reaction to be expected: lytic response due to progagation of phages by bacteria and "inhibition" (Blair \& Williams, 1961). To distinguish between the 
reaction types, phages have to be applied at various concentrations to sensitive bacteria. The lytic response of bacteria to virulent or temperate phages is indicated by plaque formation which is observed after sufficient (and generally high) dilution of the lysates in question. Inhibition is only encountered with high-titer phage lysates after no or weak dilution. It is characterized by a decrease in bacterial growth within the test area which may even simulate confluent lysis, and by the lack of plaque formation at any of the lysate dilutions used (Blair \& Williams, 1961).

A considerable portion of the findings of Moebus \& Nattkemper (1981) indicating phage sensitivity of bacteria was based on the observation of turbid spots. Three types of reaction leading to turbid spots have been considered: lysogenization of bacteria by temperate phages, development of tiny plaques which even in very large numbers do not cause clear lysis, and inhibition.

The main purpose of this investigation was to elucidate the meaning of the turbid spots formerly observed. However, since inhibition may simulate confluent lysis all phage-host systems known to produce any type of reaction between bacteria and phages were re-examined using serially diluted lysates. In addition, certain phage-host systems which yielded negative results in the PHCR tests of Moebus \& Nattkemper (1981) were tested to verify differences in phage sensitivity patterns among closely related bacterial strains.

\section{MATERIALS AND METHODS}

Me di a. The same media as given by Moebus \& Nattkemper (1981) were used.

Bacteria, bacteriophages, and their designation. All bacteria (including doublet strains) known to be sensitive to the phage strains employed by Moebus \& Nattkemper (1981) were used. In contrast, of the formerly established groups of bacteriophage doubiets only one representative phage strain was employed. The designation of bacteria and phages is the same as given by Moebus \& Nattkemper (1981). The term "original host" refers to bacteria by means of which the respective phage strain was detected, purified, and propagated for lysate preparation.

Sensitivity tests. Crude phage lysates (Moebus, 1980) were spotted on doublelayer plates (Moebus \& Nattkemper, 1981) undiluted and after 3 consecutive dilutions of about 1/100 each, produced by means of calibrated loops transferring $10 \mu l$. The spot-test plates were routinely incubated at $25^{\circ} \mathrm{C}$ overnight, however, with many phage-host systems indicating bacterial inhibition at $25^{\circ} \mathrm{C}$, parallel spot-test plates were incubated at $15^{\circ} \mathrm{C}$ ( 1 day) and at $5^{\circ} \mathrm{C}$ ( 3 days).

Identification of temperate bacteriophages. Lysates of phages producing homogeneously turbid plaques were spotted on lawns of the respective host bacteria. Small portions of confluently lysed (turbid) spots were transferred into SWB $/ 5$ and incubated overnight at $25^{\circ} \mathrm{C}$ and $1 \mathrm{rpm}$. The cultures were streaked on SWA and the plates incubated at the same temperature for 2 days. From each streak 6 colonies were picked and cleaned by, at least, 3 consecutive streaks on SWA. From the last streak 8 or more colonies were isolated and spotted on soft-SWA over-lays containing about $10^{8}$ cells/plate of the respective non-lysogenized host bacteria. After incubation at $25^{\circ} \mathrm{C}$ overnight the plates were checked for growth of phage-treated bacteria surrounded by a turbid lysis zone developed within the overlay indicating successful lysogenization of the bacteria spotted on top of the overlay. For final tests the lysogenized bacteria were 
grown in SWB/5 and the cultures checked for immunity of the cells against the respective temperate phage strain as well as for the presence (and number) of plaque forming units (PFU).

\section{RESULTS}

In this investigation the findings of Moebus \& Nattkemper (1981) indicating sensitivity of bacteria to undiluted bacteriophage lysates were re-examined by applying lysates undiluted as well as lysate dilutions of about $10^{-2}, 10^{-4}$, and $10^{-6}$ to bacteria which then were incubated at $25^{\circ} \mathrm{C}$. The observations made can be summarized as follows:

(1) Plaque formation after application of highly diluted lysate with no or little difference in the number of plaques on lawns of the phage's original host and of other bacterial strains. Results of this type are presented as circles in Figures 1 and 2.

(2) Plaque formation with highly diluted lysate on lawn of the phage's original host. but on lawns of other bacteria only after no or weak dilution, probably indicating the presence of phage mutants in the lysate. Results of this type are presented by the capital letter $\mathrm{P}$ in Figures 1 and 2.

(3) No formation of plaques with any of the lysate dilutions but confluent change in appearance of bacterial lawn in spot area after application of undiluted or weakly diluted $\left(10^{-2}\right)$ lysate. Depending on the phage titer, undiluted lysate causes totally clear to more or less turbid spot area; weakly diluted lysate produces turbid spot area, the degree of turbidity generally being very high. (Only occasionally slight change in appearance of spot area as compared to surrounding lawn was found with lysates diluted $10^{-4}$ ). Results of this type indicating inhibition of bacteria are presented as dots in Figures 1 and 2.

(4) Plaque formation in combination with changes of bacterial lawn indicating inhibition of bacteria, mostly observed only after application of undiluted lysate. Plaques generally tiny $(0.2 \mathrm{~mm} \varnothing$ or less). This type of reaction is also represented by dots in Figures 1 and 2 .

Moebus \& Nattkemper (1981) placed 225 out of 326 Atlantic Ocean (A-series) bacterial strains found to be sensitive to one or more A-series bacteriophage strain(s) into two large clusters comprising 160 (cluster 1) and 65 (cluster 2) strains, respectively. After re-examination 4 small groups of bacterial and corresponding bacteriophage strains had to be removed from cluster 1 because their formerly observed linkage to other members of this cluster could not be confirmed, mainly due to the loss of a few phage and bacterial strains in the meantime. Other changes in cluster 1 are caused by the recognition of several bacterial and phage strains as being doublets of others. Cluster 1 in its present composition, still including 128 bacterial strains, is shown in Figure 1.

With cluster 2 only minor changes occurred as compared with the results of Moebus \& Nattkemper (1981) due to some newly recognized doublets among bacteria and phages and the loss of one bacterial strain. The recent findings concerning cluster 2 are presented in Figure 2.

As the main purpose of this investigation was to solve the problem of turbid spots observed during the initial PHCR tests (Moebus \& Nattkemper, 1981), special attention was paid to the identification of temperate bacteriophage strains. All phages producing homogeneously turbid plaques on lawn of their original hosts were tested for their ability to establish lysogeny in these bacteria. Twenty-nine phage strains were found to 


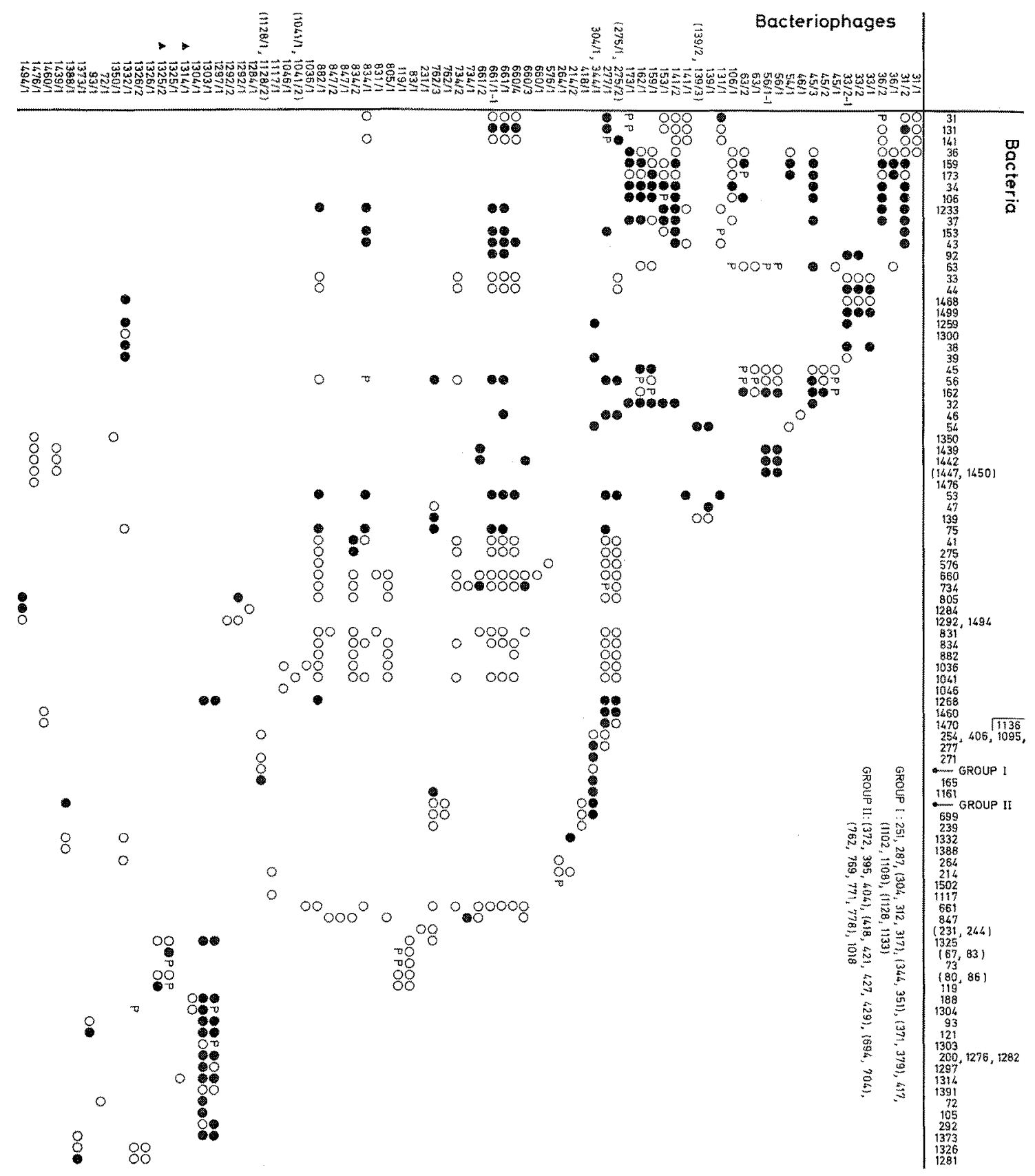

Fig. 1. Bacteriophage sensitivity patterns of Atlantic Ocean bacteria (cluster 1). Doublets of bacteria and phages are pooled; intrasample doublets are presented in parentheses. Circles: plaque formation with highly diluted phage lysate; P: plaque formation with undiluted or weakly diluted lysate; dots: inhibition of bacteria by phage; black triangles: temperate phage strain 


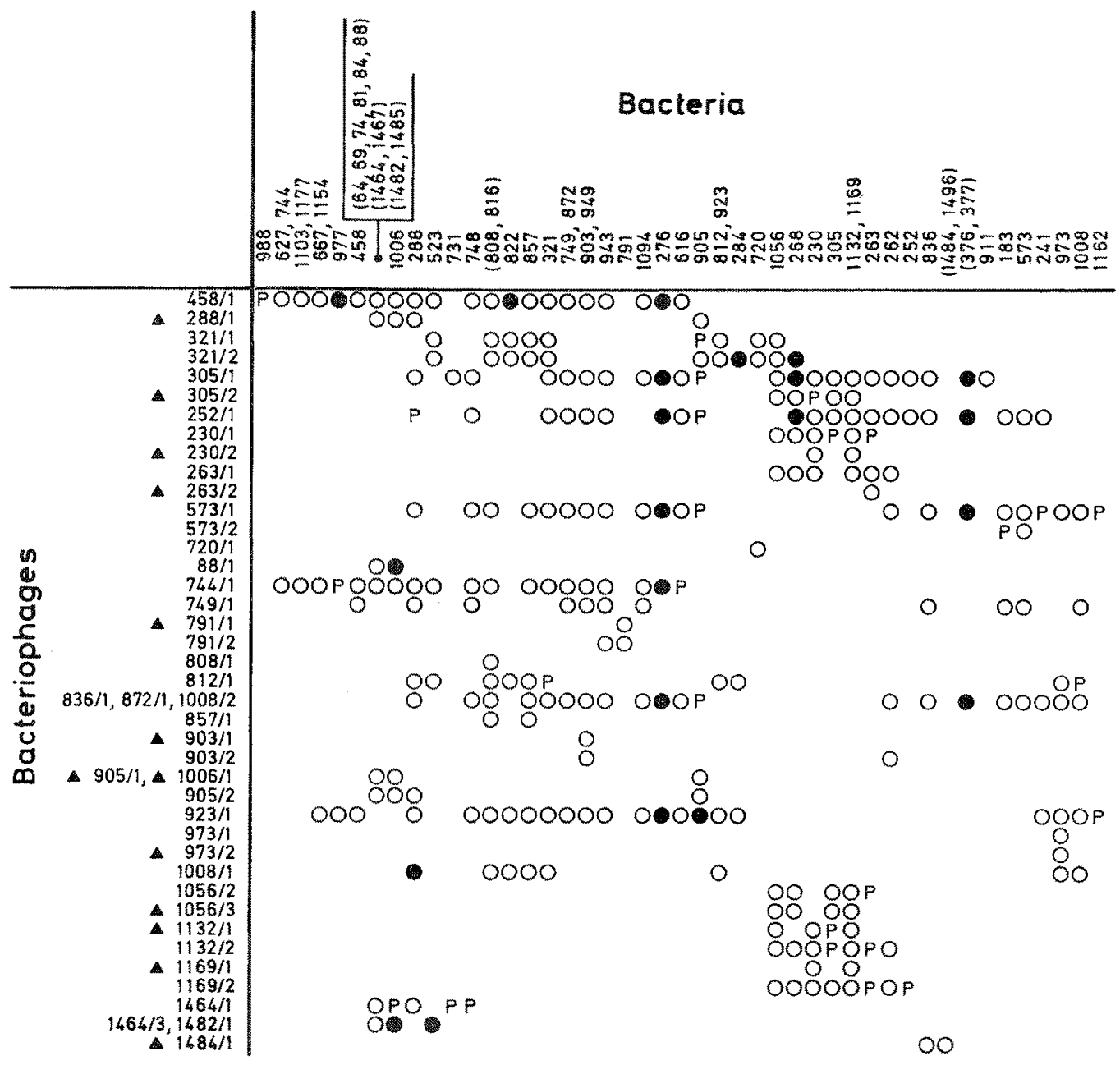

Fig. 2. Bacteriophage sensitivity patterns of Atlantic Ocean bacteria (cluster 2). Other infomation as for Figure 1

be temperate ones. In Figures 1 and 2 temperate phage strains are indicated by a black triangle in front of their designation. Thirty-three bacterial strains were found to be susceptible to lysogenization by one or more of the 29 temperate phages. In sum, lysogeny was established in 54 phage-host combinations.

As compared with lysogeny, inhibition was found to be much more important in causing turbid spots. Among the 1299 re-examined phage-host systems of the A-series, 358 are characterized by inhibition at $25^{\circ} \mathrm{C}$. Of these systems, 250 and 34 belong to clusters 1 and 2, respectively, and the remaining to other much smaller groups of related phage-host systems.

Clusters 1 and 2 differ in several aspects. In cluster 1 more than $50 \%$ of the 92 phage 
sensitivity patterns are characterized by both lytic and inhibition reactions of bacteria to phages, whereas in cluster 2 nearly $80 \%$ of the 45 patterns are characterized by lytic responses only. Inhibition by phages was observed in more than $60 \%$ of the 124 bacterial strains comprising cluster 1 but in only $17 \%$ of the 64 strains compiled in cluster 2.

Another difference between both clusters concerns the geographic origin of bacteria. (and phages). Cluster 1 combines 59 bacterial strains isolated from samples taken west of the Azores ("western" bacteria, Strain Nos. 183 to 1242) and 69 strains derived from samples collected east of these islands ("eastern" bacteria). In cluster 2 the respective numbers are 52 and 12 . From these findings the question arises whether there is any correlation between the geographic origin of bacteria and phages on the one hand and the occurrence of lytic versus inhibition reactions of bacteria to phages on the other hand.

To answer this question we refer to cluster 1 which is the best suited group of related bacteria since it combines not only the largest number of strains but also about equal numbers of "eastern" and "western" bacteria derived from 36 out of 48 water samples collected between the European continental shelf and the Sargasso Sea. In 109 bacterial strains, excluding intrasample bacterial and phage doublets, sensitivity to any of the 80 bacteriophage strains was observed 568 times comprising 358 lytic and 210 inhibition reactions. Forty-three "western" bacteria reacted to "western" ("eastern") phages 172 (5) times by lytic response and 27 (16) times by inhibition. In sharp contrast to this, in 66 "eastern" bacteria the reaction to "eastem" ("western") bacteriophage strains was characterized 145 (36) times by lysis and 109 (58) times by inhibition.

These figures clearly show that lysis occurred more often among "western" phagehost systems than among "eastern" ones ( $86.4 \%$ versus $57.1 \%$ ) while inhibition was observed much more often in "eastern" in "western" systems $(42.9 \%$ versus $13.6 \%)$. With phage-host systems one part of which is of eastern and the other of western origin ("east-west" systems) inhibition was found more often (74 times) than lysis (41 times).

As discussed by Moebus \& Nattkemper (1981), these differences between "eastern" and "western" phage-host systems may be due to genetic changes occurring while the bacteria and phages are transported from west to east. The present information, therefore, was used to detect, if possible, correlations between the type of reaction of bacteria to phages and the distance between the geographic origins of both parts of the phagehost systems.

Figure 3 depicts the numbers of lytic responses (white columns) and inhibition reactions (black columns) in relation to the shortest distance between stations as observed with bacteria and phages of cluster 1 . For the compilation of data only one of several phage-host systems derived from the same station(s) was taken into consideration. For example, if phages A and B of Station 1 both lyse bacteria k of Station 9, and if phage $B$ of Station 1 lyses bacteria o and $p$ of Station 11 as well as bacteria $q$ and $r$ of Station 12 but inhibits bacteria s of the latter station, only the combinations $A-k, B-0$, $B-q$ (for lysis) and B-s (for inhibition) were used. However, if phage C of Station 2 lyses bacteria $q$ of Station 12 and phage $Q$ of Station 12 lyses bacteria $\mathrm{c}$ of Station 2 , both combinations $(\mathrm{C}-\mathrm{q}$ and $\mathrm{Q}-\mathrm{C})$ were counted. In this way, the bias resulting from differences in the numbers of phage-host systems, both parts of which were derived from the same sample(s), was avoided. 
The shortest distance between stations was calculated and combined in distance classes of 100 nautical miles each $(0,1$ to 100,101 to $200 \mathrm{n}$. m., and so on). The numbers of pairs of stations belonging to the various distance classes are indicated by dots (Fig. 3).

The findings obtained with phage-host systems, both parts of which were isolated either from the same region (east or west of the Azores, respectively) or from both regions, are shown separately in Figure 3. In "eastern" systems, roughly equal numbers of lytic and inhibition reactions were found for stations falling within the same distance class, emphasizing the commonness of inhibition responses among "eastern" phagehost systems. In stark contrast to this, in "western" systems, an increase in the number of inhibition reactions relative to lytic responses was observed with increasing distance between stations. Among "east-west" phage-host systems, inhibition responses occurred

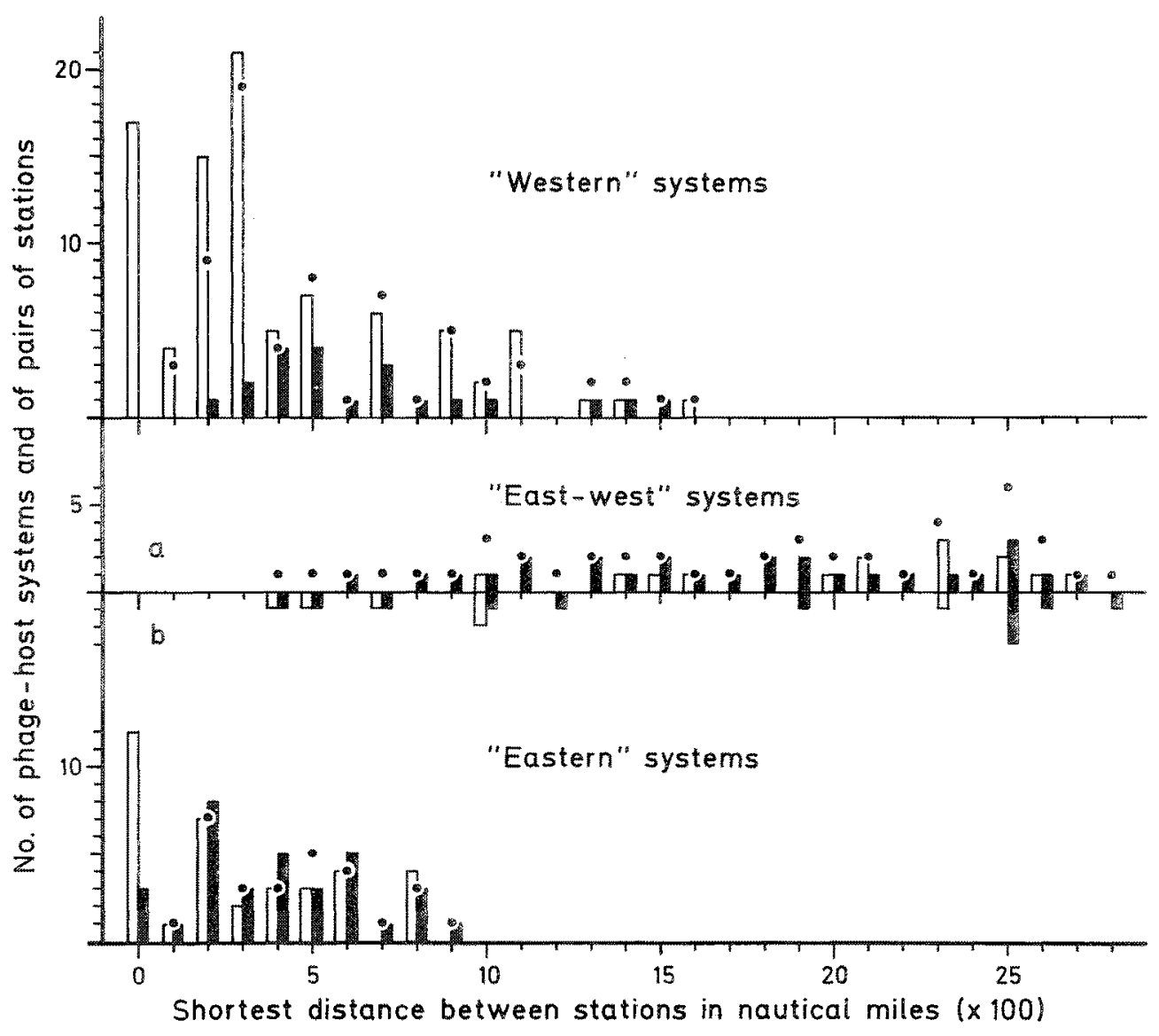

Fig. 3. Frequencies of lytic (white columns) and inhibition responses (black columns) of bacteria to phages in relation to shortest distance between stations where bacteria and phages are derived (cluster 1). "East-west" systems: Findings obtained with systems combining "western" phages with "eastern" bacteria (a) and "eastern" phages with "western" bacteria (b) are shown separately. Dots: number of pairs of stations belonging to distance classes. For further information see text 
more often (41 times) than lytic ones (17 times), however, the frequency of both reaction types is not correlated with the distance between stations but with the number of pairs of stations belonging to the same distance class.

As stated above, cluster 2 differs from cluster 1 (Figs 2 and 1, respectively) in several aspects. It combines only 394 phage-host systems (intrasample doublets of bacteria excluded); merely 28 of them yielding inhibition reactions. Of the 394 systems, 333 are "western" ones including 23 systems of the inhibition type. In 13 "eastern" systems, only lytic responses were found. Among 28 "east-west" phage-host systems, inhibition was observed with 5 systems combining "eastern" phages with "western" bacteria.

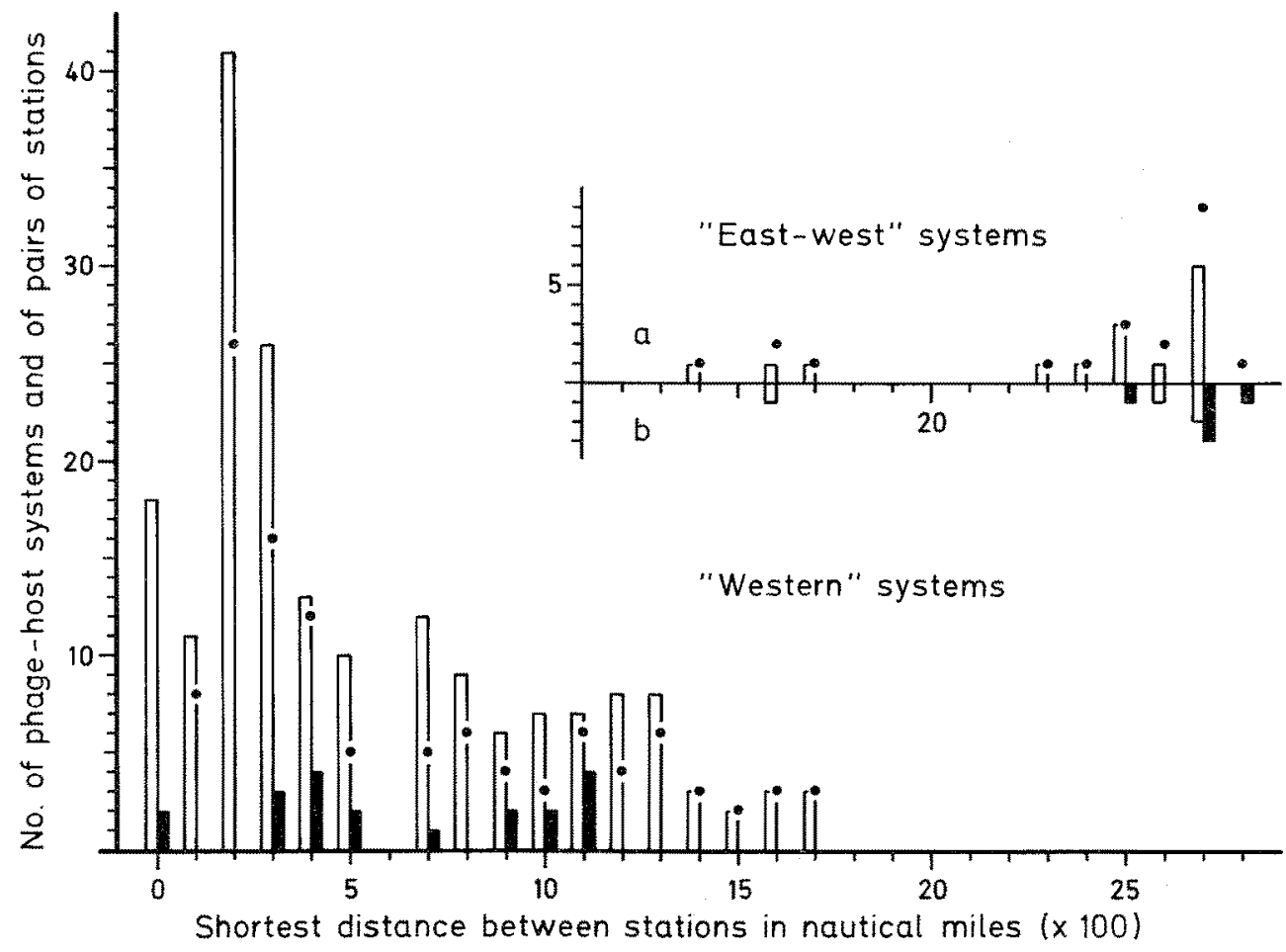

Fig. 4. Frequencies of lytic (white columns) and inhibition responses (black columns) of bacteria to phages in relation to shortest distance between stations where bacteria and phages were derived (cluster 2). Other information as for Figure 3

Figure 4 presents the numbers of lytic and inhibition responses in relation to the distance between stations where the bacterial and bacteriophage strains included in cluster 2 were derived. The data were calculated as described above. As found with cluster 1 , in "western" systems of cluster 2 the number of inhibition reactions in relation to that of Iytic responses tends to increase with the distance between stations.

All the observations of inhibition of bacteria by phages referred to above were made with incubations at $25^{\circ} \mathrm{C}$. Preliminary tests showed that instead of inhibition, as found at $25^{\circ} \mathrm{C}$, plaque formation may occur at reduced temperatures. Therefore, 269 out of the 
Table 1. Types of reaction among 269 phage-host systems (A-series) characterized by inhibition at $25^{\circ} \mathrm{C}$, as observed with spot-test plates incubated at $15^{\circ}$ and $5^{\circ} \mathrm{C}$, respectively

\begin{tabular}{|lr|}
\hline \multicolumn{1}{|c|}{ Type of reaction } & $\begin{array}{c}\text { No. of phage-host } \\
\text { systems }\end{array}$ \\
\hline Inhibition at $15^{\circ}$ and $5^{\circ} \mathrm{C}$ & 197 \\
Inhibition at $15^{\circ} \mathrm{C}$, no lawn formed at $5^{\circ} \mathrm{C}$ & 16 \\
Inhibition at $15^{\circ} \mathrm{C}$, no reaction at $5^{\circ} \mathrm{C}$ & 1 \\
No reaction at $15^{\circ}$ and $5^{\circ} \mathrm{C}$ & 1 \\
Plaque formation at $5^{\circ} \mathrm{C}$, inhibition at $15^{\circ} \mathrm{C}$ & 6 \\
Plaque formation at $15^{\circ} \mathrm{C}$, inhibition at $5^{\circ} \mathrm{C}$ & 7 \\
Plaque formation at $15^{\circ} \mathrm{C}$, no reaction at $5^{\circ} \mathrm{C}$ & 1 \\
Plaque formation at $15^{\circ}$ and $5^{\circ} \mathrm{C}$ & 23 \\
about the same at both temperatures & 12 \\
more plaques at $5^{\circ}$ than at $15^{\circ} \mathrm{C}$ & 5 \\
more plaques at $15^{\circ}$ than at $5^{\circ} \mathrm{C}$ & \\
\hline
\end{tabular}

358 phage-host systems characterized by inhibition at $25^{\circ} \mathrm{C}$ (see above) were also tested at $5^{\circ}$ and $15^{\circ} \mathrm{C}$. The results are compiled in Table 1.

In 54 of the 269 phage-host systems tested at the 3 temperatures, plaque formation was observed at $5^{\circ}$ and/or $15^{\circ} \mathrm{C}$. It must be emphasized, however, that the ability of phage strains to cause plaque formation at these temperatures with any of the tested bacteria varied greatly as compared with their plaquing efficiency observed with the respective original host at $25^{\circ} \mathrm{C}$, the latter being $100 \%$. In some cases, the plaquing efficiency was about $100 \%$, but in most systems it was reduced to between about 0.1 and $1 \%$, and in others, plaques were formed only after application of undiluted lysate (i. e. plaquing efficiency between $10^{-5}$ and $10^{-7}$ ). If plaques were formed at $5^{\circ}$ and $15^{\circ} \mathrm{C}$, they generally were larger in plates incubated at the lower temperature.

Spot tests, as useful as they are, can provide rough information only. More reliable results are obtained when double layer plates are poured with several dilutions of the phage lysates in question and incubated at various temperatures. Therefore, a group of 6 bacterial and 10 bacteriophage strains (see Table 2) was selected from cluster 1 for a more detailed investigation. Among these 60 phage-host systems, various types of reaction (i. e. plaque formation or inhibition, depending on incubation temperature, or no reaction at all) were known to occur from preceeding spot tests.

At first, spot tests were performed with fresh lysates originating from single plaques to check former results. In general, very good conformity between new and old observations was found at the 3 temperatures mentioned above. Later on, with the various sensitive bacterial strains and several dilutions of the phage lysates double-layer plates were poured and incubated as stated before. From plates incubated at $15^{\circ}$ and $25^{\circ} \mathrm{C}$, respectively, representative plaques were isolated and eluted in $1 \mathrm{ml}$ of sterile seawater each at the respective temperature. The eluates then were serially diluted and spot tested on lawns of bacteria sensitive to the phage strain in question and the plates incubated at the 3 temperatures.

Table 2 presents plaquing efficiencies as calculated from the number of plaques found in each of the phage-host systems at the 3 temperatures, the value 1 representing 
Table 2. Plaquing efficiencies of selected phage-host systems as observed with double-layer plates incubated at $25^{\circ}, 15^{\circ}$, and $5^{\circ} \mathrm{C}$, respectively, Symbols: - no reaction, $\mathrm{T}=$ inhibition, $(\mathrm{T})=$ inhibition observed with spot-test plates, $M=$ microplaques

\begin{tabular}{|c|c|c|c|c|c|c|c|}
\hline \multirow{2}{*}{$\begin{array}{l}\text { Phage } \\
\text { strain. }\end{array}$} & \multirow{2}{*}{$\begin{array}{l}\text { Tested } \\
\text { at }{ }^{\circ} \mathrm{C}\end{array}$} & \multicolumn{6}{|c|}{ Bacterial strains } \\
\hline & & A45 & A56 & A63 & A106 & A159 & $\mathrm{A} 162$ \\
\hline \multirow{3}{*}{ A. $45 / 1$} & 25 & 0.75 & $6 \times 10^{-3}$ & 0.50 & - & - & $8 \times 10^{-5}$ \\
\hline & 15 & 1 & 0.65 & 1 & - & - & $3 \times 10^{-5}$ \\
\hline & 5 & 0.17 & 0.06 & 0.50 & - & - & i \\
\hline \multirow{3}{*}{ A $45 / 2$} & 25 & 0.30 & 0.14 & - & - & - & $-(\mathrm{I})$ \\
\hline & 15 & 1 & 0.34 & 0.01 & - & - & $\mathbb{I}$ \\
\hline & 5 & 0.64 & 0.11 & $5 \times 10^{-3}$ & - & - & I \\
\hline \multirow{3}{*}{ A $45 / 3$} & 25 & 0.17 & $\underline{I}$ & I & $\frac{\gamma}{3}$ & I & 1 \\
\hline & 15 & 1 & 0.01 & $10^{-3}$ & 1 & 0.39 & 1 \\
\hline & 5 & 0.80 & 0.03 & $6 \times 10^{-6}$ & $\mathbb{I}$ & 0.30 & I \\
\hline \multirow{3}{*}{ A $56 / 1$} & 25 & 0.50 & 0.50 & $4 \times 10^{-5}$ & - & - & $-(\mathrm{I})$ \\
\hline & 15 & $\mathbf{1}$ & 0.50 & $7 \times 10^{-3}$ & - & - & $-(\mathrm{I})$ \\
\hline & 5 & 1 & 0.18 & $3 \times 10^{-5}$ & - & - & I \\
\hline \multirow{3}{*}{ A $56 / 1-1$} & 25 & 0.17 & 0.39 & $3 \times 10^{-6}$ & - & - & I \\
\hline & 15 & 0.60 & 1 & $3 \times 10^{-6}$ & - & - & I \\
\hline & 5 & 0.31 & 0.39 & $5 \times 10^{-7}$ & - & - & I \\
\hline \multirow{3}{*}{ A $63 / 1$} & 25 & 0.96 & $5 \times 10^{-6}$ & 0.66 & - & - & 0.06 \\
\hline & 15 & 0.96 & 1 & 0.81 & - & - & 0.17 \\
\hline & 5 & 0.30 & 0.35 & 0.66 & - & - & $2 \times 10^{-5}$ \\
\hline \multirow{3}{*}{ A $63 / 2$} & 25 & $10^{-6}$ & $5 \times 10^{-7}$ & 0.20 & I & 1 & I \\
\hline & 15 & $1, M ?$ & 0.67 & 1 & I & 0.44 & $2 \times 10^{-5}$ \\
\hline & 5 & $2 \times 10^{-6}$ & 0.31 & 0.65 & I & 0.44 & $10^{-5}$ \\
\hline \multirow{3}{*}{$\mathrm{A} 106 / 1$} & 25 & - & - & $4 \times 10^{-6}$ & 0.42 & 0.34 & - \\
\hline & 15 & - & $10^{-3}$ & $5 \times 10^{-6}$ & 0.17 & 1 & - \\
\hline & 5 & - & $10^{-6}$ & $3 \times 10^{-6}$ & $\mathrm{I}, \mathrm{M}$ & 0.61 & - \\
\hline \multirow{3}{*}{$\mathrm{A} 159 / 1$} & 25 & $-(I)$ & 0.39 & 0.43 & $2 \times 10^{-6}$ & 0.56 & $6 \times 10^{-5}$ \\
\hline & 15 & $-(I)$ & 0.35 & 0.98 & I & 1 & $2 \times 10^{-4}$ \\
\hline & 5 & I & 0.12 & 0.71 & 1 & 0.70 & 0.04 \\
\hline \multirow{3}{*}{$\mathrm{A} 162 / 1$} & 25 & $-(\mathrm{I})$ & $2 \times 10^{-5}$ & 0.23 & $\Upsilon$ & I & 0.76 \\
\hline & 15 & I & 0.33 & 0.59 & 1 & I & 1 \\
\hline & 5 & $I$ & 0.17 & 0.44 & I & $5 \times 10^{-6}$ & 0.40 \\
\hline
\end{tabular}

the highest plaque count observed. As can be seen, incubation at $15^{\circ} \mathrm{C}$ yielded the highest plaque number with all 10 phages, though not always with the phages' original hosts. The effect of temperature causes little surprise since these phage-host systems were isolated from Atlantic Ocean water the temperature of which ranged from $8^{\circ}$ to $16^{\circ} \mathrm{C}$ (Moebus, 1980). It is, however, surprising to find results such as those with phage strains A63/1 and A106/1.

Phage A63/1 yielded the highest plaque count with the marine bacterial (MB) strain A56 at $15^{\circ} \mathrm{C}: 1.9 \times 10^{9} \mathrm{PFU} \mathrm{m} \mathrm{m}^{-1}$. The plaque diameter was about $1.5 \mathrm{~mm}$. With the same host the plaquing efficiency at $25^{\circ} \mathrm{C}$ was only $5 \times 10^{-6}$ and the plaque size about $1 \mathrm{~mm}$ in diameter. As revealed by subsequent spot tests of single plaque eluates, phage A63/1 
plaques grown with MB A56 at $15^{\circ}$ or $25^{\circ} \mathrm{C}$ always yielded much less progeny phages than could be expected according to plaque size, irrespective of growth conditions (MBs $\mathrm{A45}, \mathrm{A} 56, \mathrm{~A} 63$, and A106 as hosts at the 3 temperatures). Eluates of plaques grown with MB A.56 at $15^{\circ} \mathrm{C}$ even yielded no plaques at all with this host at $25^{\circ} \mathrm{C}$.

In contrast, with its original host (MB A63) phage A63/1 produced a similar number of plaques (between $1.2 \times 10^{9}$ and $1.5 \times 10^{9} \mathrm{PFU} \mathrm{\textrm {ml } ^ { - 1 }}$ ) at the 3 temperatures. The size of these plaques was about $3 \mathrm{~mm}\left(25^{\circ} \mathrm{C}\right), 4 \mathrm{~mm}\left(15^{\circ} \mathrm{C}\right)$, and 2 to $7 \mathrm{~mm}\left(5^{\circ} \mathrm{C}\right)$ in diameter. Very large numbers of progeny phages were eluted from plaques grown at $15^{\circ}$ and $25^{\circ} \mathrm{C}$, their plaquing efficiencies comparing favourably with those observed for the $A 63 / 1$ lysate under the various growth conditions. With $A 63 / 1$ plaques grown with MB A45, rather similar observations were made.

The other aforementioned bacteriophage strain yielding surprising results is A106/ 1. With this phage the highest plaque number was found with $\mathrm{MB} A 159$ at $15^{\circ} \mathrm{C}: 6 \times 10^{8}$ PFU $\mathrm{ml}^{-1}$, the plaque diameter being about $0.3 \mathrm{~mm}$. From these plaques no progeny phages at all were detected with eluates spotted on lawns of MBs A63, A106, and A159 and incubated at the 3 temperatures, whereas the even smaller plaques $(0.2 \mathrm{~mm} \varnothing)$ grown with $\mathrm{MB}$ A159 at $25^{\circ} \mathrm{C}$ yielded reasonable numbers of progeny PFU with MB A 159 at all 3 temperatures but with $\mathrm{MBs} A 63$ and $\mathrm{A} 106$ at $25^{\circ} \mathrm{C}$ only.

When phage $A 106 / 1$ is grown with its original host (MB A106) it produces plaques of about $1 \mathrm{~mm}$ in diameter at $25^{\circ} \mathrm{C}$ but much smaller ones (less than $0.2 \mathrm{~mm} \varnothing$ ) at a slightly reduced rate at $15^{\circ} \mathrm{C}$. The latter plaques yielded no progeny phages irrespective of growth conditions, as observed with $\mathrm{A} 106 / 1$ plaques grown with $\mathrm{MB} A 159$ at $15^{\circ} \mathrm{C}$. With progeny phages from plaques grown at $25^{\circ} \mathrm{C}$, spot tested on lawns of MBs A63, A106, and $\mathrm{A} 159$, observations were made which perfectly correspond with the findings obtained by titration of phage A106/1 lysate with the same bacterial hosts.

Similar observations were made with plaque eluates produced for other phage-host systems. Provided that the plaquing efficiency of a phage strain with one of its hosts at a specific temperature was not greatly reduced and the plaque size similar to that occurring with its original host at $25^{\circ} \mathrm{C}$, the results found with plaque eluates generally corresponded fairly well with the observations made after titration of the respective phage's lysate with the various host bacteria at the 3 temperatures. Otherwise one was likely to find only a few or no progeny PFU at all even with plaques of considerable size $(0.5$ to $1.5 \mathrm{~mm} \varnothing)$.

Attempts to produce stable phage populations from plaques yielding only few progeny phages were always unsuccessful. In the course of 2 to 3 successive cycles of phage propagation the number of progeny phages per plaque generally decreased, often to nil.

In some cases the results obtained with spot tested eluates of plaques grown at $15^{\circ}$ and $25^{\circ} \mathrm{C}$ pointed to the possibility that temperature dependent mutants of the respective phage strain were selected. Experiments performed with phage A45/1 propagated with $\mathrm{MB}$ A162 lead to the isolation of two such mutants which show little difference in plaquing efficiency with MBs $\mathrm{A} 45$ and $\mathrm{A} 162$ at $15^{\circ} \mathrm{C}$. At $25^{\circ} \mathrm{C}$ these mutants with both hosts produce much less and much smaller plaques (about $0.5 \mathrm{~mm} \varnothing$ ) from which no or negligible numbers of progeny phages were found. One of the mutants readily produces new mutants which efficiently form plaques with MB A162 at $15^{\circ}$ as well as at $25^{\circ} \mathrm{C}$. They are easily distinguished by plaque size which, after incubation at $15^{\circ} \mathrm{C}$, is 4 to 
$5 \mathrm{~mm}$ instead of about $2 \mathrm{~mm}$ in diameter for the parental mutants which reproduce only at this temperature.

As reported by Moebus \& Nattkemper (1981, Fig. 4), 47 bacterial strains derived from Atlantic water samples were found to be sensitive to 11 phage strains isolated from the North Sea (H-series) between 1976 and 1978. These observations are of special interest in so far as the results of Moebus \& Nattkemper (1981) indicated considerable variation in phage sensitivity patterns even among bacteria which were isolated from Atlantic water samples collected at adjacent stations (about 200 nautical miles apart). Therefore, the observed sensitivity of A-series bacteria to phages isolated from the North Sea was surprising, all the more so as 36 of the 47 sensitive A-series bacteria were collected west of the Azores. In most cases, sensitivity was indicated by turbid spots pointing to the possibility that inhibition was the prevalent type of reaction between $\mathrm{H}$ series phages and A-series bacteria.

As with phage-host systems of the A-series, several dilutions of the respective $\mathrm{H}$ series phage lysates were spot tested on lawns of sensitive A-series bacteria. Three of the phage strains used by Moebus \& Nattkemper (1981) could not be employed since either the phage (H30/2) or the hosts (MBs A21 and A417 for phages H32/1 and H44/4, respectively) had been lost in the meantime. However, 7 A-series bacteria not included in the presentation by Moebus \& Nattkemper (1981) were used during this remexamination. In sum, $87 \mathrm{H}$-phage-A-host systems were spot tested at $5^{\circ}, 15^{\circ}$, and $25^{\circ} \mathrm{C}$. Twentythree of the 87 systems were also tested in liquid culture at $15^{\circ}$ and $25^{\circ} \mathrm{C}$.

Liquid culture was employed when spot tests yielded ambiguous results as, for example, the development of microplaques (diameter $0.1 \mathrm{~mm}$ or less). SWB/5 was inoculated with freshly grown cells of the A-series bacteria to an initial titer of about $2 \times 10^{6} \mathrm{CFU} \mathrm{m} \mathrm{m}^{-1}$ and with about $10^{5} \mathrm{PFU} \mathrm{ml}^{-1}$ of the respective $\mathrm{H}$-series phage. Before incubation for 24 hours at $1 \mathrm{rpm}$ and $15^{\circ}$ and $25^{\circ} \mathrm{C}$, respectively, the initial PFU titer was determined by titration with the original $\mathrm{H}$-series hosts of the phages in question. After incubation, the cultures were centrifuged to remove bacteria and the supernatants

Table 3. Types of reaction among 87 A-series bacteria to H-series bacteriomphages as revealed by spotwtest plates incubated at $25^{\circ}, 15^{\circ}$, and $5^{\circ} \mathrm{C}$, respectively, and by liquid culture at $25^{\circ}$ and $15^{\circ} \mathrm{C}$, respectively (combined results)

Type of reaction

No. of phage-host systems

Inhibition at all temperatures

Inhibition at $25^{\circ}$ and $15^{\circ} \mathrm{C}$, no reaction at $5^{\circ} \mathrm{C}$

Inhibition at $25^{\circ}$ and $15^{\circ} \mathrm{C}$, no lawn formed at $5^{\circ} \mathrm{C}$

Plaque formation and/or phage propagation in liquid culture at $25^{\circ} \mathrm{C}$ only, inhibition at $15^{\circ}$ and $5^{\circ} \mathrm{C}$ at $25^{\circ} \mathrm{C}$ only, no reaction at $15^{\circ}$ and $5^{\circ} \mathrm{C}$ at $25^{\circ}$ and $15^{\circ} \mathrm{C}$, inhibition at $5^{\circ} \mathrm{C}$ at $25^{\circ}$ and $15^{\circ} \mathrm{C}$, no lawn formed at $5^{\circ} \mathrm{C}$ at $25^{\circ}$ and $15^{\circ} \mathrm{C}$, no reaction at $5^{\circ} \mathrm{C}$ at all temperatures 
titrated as mentioned before. By this method, with 8 of the 23 phage-host systems tested in liquid culture, phage propagation could be demonstrated to occur at $15^{\circ}$ and/or $25^{\circ} \mathrm{C}$.

The combined results of experiments performed with H-phage-A-host systems are presented in Table 3 . In a considerable portion of these systems inhibition was observed. However, more important is the fact that in $51(=59 \%)$ of the 87 systems investigated plaque formation in spot-test plates and/or phage propagation in liquid culture was found with, at least, one of the temperature regimes employed. In most cases, the observed plaques were small (up to $0.5 \mathrm{~mm} \varnothing$ ) or tiny $(0.1$ to $0.2 \mathrm{~mm} \varnothing$ ). However, it must be pointed out that the respective phages produce relatively small plaques 10.6 to $0.8 \mathrm{~mm} \varnothing$ ) with their original $H$-series hosts, too.

Similar experiments were performed with phage strain B14/2 (isolated 1978 from a Bay of Biscay water sample) and 23 strains of A-series bacteria (see Moebus \& Nattkemper, 1981, Fig. 4). Only 5 of these phage-host systems are characterized by inhibition. In the other 18 systems phage propagation was observed, at least, at one of the 3 incubation temperatures.

Finally the results obtained with a group of 9 A-series bacteria (cluster 14) which are conspicuously different from the other phage sensitive A-series strains (Moebus \& Nattkemper, 1983) shall be presented. Five of these strains (A185, A335, A400, A432, and A929) grow profusely in SWB at $37^{\circ} \mathrm{C}$, forming large flakes under this and other conditions. This observation casts doubt on the marine nature of these strains. On the other hand, however, close relationship among the 9 strains is indicated by their

Table 4. Cluster 14: Sensitivity of bacteria to, and lysogenization by, 7 bacteriophage strains. Symbols: $\mathrm{O}=$ plaque formation with highly diluted lysate, $\mathrm{P}=$ plaque formation with undiluted or weakly diluted lysate, $1=$ inhibition, $+=$ lysogenization observed, - = lysogenization not observed, ? = lysogenization uncertain, $n t=$ not tested

\begin{tabular}{|c|c|c|c|c|c|c|c|c|c|}
\hline \multirow[t]{2}{*}{ Phage strain } & \multicolumn{9}{|c|}{ Bacterial strain } \\
\hline & A185 & A335 & A398 & A400 & A432 & A897 & A929 & A1212 & A1409 \\
\hline $\mathrm{A} 185 / 1$ & $\mathrm{O} /+$ & - & - & - & - & - & - & - & - \\
\hline A398/1 & $\mathrm{P} /-$ & $\mathrm{P} /+$ & $\mathrm{O}+$ & $\mathrm{P} / \mathrm{t}$ & $\mathrm{O} /-$ & $\mathrm{P} /-$ & $\mathrm{P} /+$ & $\mathrm{P} /-$ & I \\
\hline A398/1-1 & $\mathrm{p} /-$ & $\mathrm{P} / \mathrm{t}$ & $\mathrm{O} / \mathrm{t}$ & $\mathrm{P} /+$ & $\mathrm{o} / \mathrm{-}$ & $\mathrm{P} /-$ & $\mathrm{p} /+$ & $\mathrm{p} /-$ & I \\
\hline $\mathrm{A} 400 / 1$ & $\mathrm{P} /-$ & $\mathrm{O} / \mathrm{+}$ & $\mathrm{P} /+$ & $\mathrm{O}+$ & $\mathrm{p} /-$ & $\mathrm{P} /+$ & $\mathrm{p} /+$ & $\mathrm{P} / \mathrm{-}$ & - \\
\hline $\mathrm{A} 400 / 1-1$ & $\mathrm{P} /-$ & $\mathrm{O} / \mathrm{t}$ & $\mathrm{O}+$ & $\mathrm{o} / \mathrm{t}$ & $\mathrm{O} / \mathrm{t}$ & $\mathrm{O} /-$ & $\mathrm{p} /+$ & $\mathrm{P} / \mathrm{+}$ & I \\
\hline $\mathrm{A} 400 / 2$ & - & $\mathrm{O} / \mathrm{t}$ & $\mathrm{O} /$ & $\mathrm{O} / \mathrm{t}$ & $\mathrm{O} / \mathrm{t}$ & $\mathrm{P} /+$ & $\mathrm{P} / \mathrm{t}$ & $\mathrm{p} / \mathrm{+}$ & 1 \\
\hline $\mathrm{A} 432 / 1$ & $\mathrm{P} /-$ & $\mathrm{P} / \mathrm{t}$ & $\mathrm{P} /$ ? & $\mathrm{P} /+$ & $\mathrm{O} / \mathrm{t}$ & $\mathrm{P} / \mathrm{nt}$ & - & $\mathrm{P} /+$ & - \\
\hline
\end{tabular}

sensitivity patterns to 7 phages which all are temperate ones. As can be seen from Table 4, eight of the bacterial strains (which are "western" ones) could be lysogenized by at least one of the phage strains. In contrast, the one "eastern" strain (A1409) is inhibited by 4 phage strains.

Experiments in liquid culture were performed with selected phage-host systems to investigate phage propagation under various growth conditions. The media used differed in the salt contents $\left(7.5 \% \mathrm{NaCl}_{1} 5 \%\right.$ sea salts, SWB $)$ or in the organic nutrient concentration (SWB/5). Incubation as still culture was at $20^{\circ}, 25^{\circ}$, or $37^{\circ} \mathrm{C}$. Initial PFU titers were about $10^{5} \mathrm{ml}^{-1}$. Irrespective of the phage-host system tested the phage titer 
Table 5. Cluster 14: Growth of bacteria and propagation of bacteriophages related to growth conditions. Symbols for bacterial growth: $n=$ no, $w=$ weak, $m=$ moderate, $p=$ profuse growth, $F$ = flake formation. Symbols for phage propagation: $-=$ decrease in PFU titer, $0=$ no change, $\pm=$

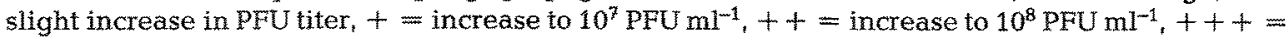
increase to $10^{9} \mathrm{PFU} \mathrm{mm^{-1 }}++++=$ increase to $10^{10} \mathrm{pFU} \mathrm{mm^{-1 }}$, intermediate final pFU titers indicated by $(+)$. Note: Growth of bacteria and phage propagation were determined in separate cultures. PFU were determined on original host of phage strain

\begin{tabular}{|c|c|c|c|c|c|c|c|c|c|c|c|}
\hline \multirow{2}{*}{$\begin{array}{l}\text { Phage } \\
\text { strain }\end{array}$} & \multirow{2}{*}{$\begin{array}{l}\text { Bacterial } \\
\text { strain }\end{array}$} & \multicolumn{10}{|c|}{ Growth condition } \\
\hline & & \multicolumn{2}{|c|}{$\begin{array}{c}7.5 \% \mathrm{NaCl} \\
20^{\circ} \mathrm{C}\end{array}$} & \multicolumn{2}{|c|}{$\begin{array}{c}5 \% \text { Sea salts } \\
20^{\circ} \mathrm{C}\end{array}$} & \multicolumn{2}{|r|}{$\begin{array}{l}\text { SWB } \\
20^{\circ} \mathrm{C}\end{array}$} & \multicolumn{2}{|r|}{$\begin{array}{l}\text { SWB } \\
37^{\circ} \mathrm{C}\end{array}$} & \multicolumn{2}{|r|}{$\begin{array}{l}\text { SWB } / 5 \\
25^{\circ} \mathrm{C}\end{array}$} \\
\hline A185/1 & A. 185 & $\mathrm{~m}$ & \pm & $p$ & $+4+4$ & $\mathrm{pF}$ & +++ & $p F$ & $+4+4$ & $p$ & $+++(+)$ \\
\hline \multirow{2}{*}{ A398/1 } & A 398 & & 0 & $w$ & + & $p$ & $+++t+1$ & 0 & - & $\mathrm{p}$ & $++(+)$ \\
\hline & A 432 & $\mathrm{mF}$ & 0 & $\mathrm{mF}$ & + & $p F$ & $+(+\infty)$ & $\mathrm{pF}$ & $+(+)$ & $\mathrm{p}$ & $+(+)$ \\
\hline \multirow{2}{*}{ A398/1-1 } & A 398 & & 0 & $w$ & + & $\mathrm{p}$ & $++(+)$ & 0 & - & $\mathrm{p}$ & $++(+)$ \\
\hline & A 432 & $\mathrm{mF}$ & 0 & $m F$ & + & $\mathrm{pF}$ & $+(+)$ & $\mathrm{pF}$ & $+(+)$ & $\mathrm{p}$ & $+(+)$ \\
\hline \multirow{2}{*}{ A.400/1 } & A 335 & $\mathbf{m}$ & $+(+)$ & $\mathrm{p}$ & ++ & $\mathrm{pF}$ & $+t+$ & $\mathrm{pF}$ & $++t+$ & $\mathrm{p}$ & $+t+(+)$ \\
\hline & A 400 & $\mathrm{mF}$ & + & $\mathrm{pF}$ & + & $\mathrm{pF}$ & ++ & $\mathrm{pF}$ & $+t+t$ & $\mathrm{p}$ & +++ \\
\hline \multirow{2}{*}{$\mathrm{A} 400 / 1-1$} & A 335 & $\mathrm{~m}$ & $+t$ & $p$ & $+t$ & $\mathrm{pF}$ & $+t+$ & $\mathrm{pF}$ & $\frac{1}{2}+t$ & $\mathrm{p}$ & $++t+1$ \\
\hline & A 400 & $\mathrm{mF}$ & $+t+$ & $\mathrm{pF}$ & $+t+$ & $\mathrm{pF}$ & $4++4$ & $p_{F}^{F}$ & $+4++$ & p & $+t+t$ \\
\hline \multirow{3}{*}{$\mathrm{A} 400 / 2$} & A 335 & $\mathrm{~m}$ & $+(+)$ & $\mathrm{p}$ & $+(+)$ & $\mathrm{pF}$ & $4+(+1)$ & $\mathrm{pF}$ & ++ & $p$ & $+t+$ \\
\hline & A 398 & $\mathrm{w}$ & 0 & w & 0 & $\mathrm{p}$ & + & 0 & - & $\mathrm{p}$ & ++ \\
\hline & A 400 & $\mathrm{mF}$ & $++(+)$ & $\mathrm{pF}$ & $+t$ & $\mathrm{pF}$ & ++4 & $\mathrm{pF}$ & $++(+)$ & $\mathrm{p}$ & +++ \\
\hline \multirow{4}{*}{$\mathrm{A} 432 / 1$} & A 335 & $\mathrm{~m}$ & $+t$ & $\mathrm{p}$ & 0 & $p^{F}$ & $4+$ & $\mathrm{pF}$ & $+t+$ & $p$ & $++(+)$ \\
\hline & A 398 & $w$ & + & w & + & $\mathrm{p}$ & $+t+$ & 0 & - & $p$ & +++ \\
\hline & A 432 & $\mathrm{mF}$ & + & $\mathrm{mF}$ & $+t+(t)$ & $\mathrm{pF}$ & ++++ & $\mathrm{pF}$ & - & $\mathrm{p}$ & $+++(+)$ \\
\hline & A1212 & 0 & \pm & $\mathrm{m}$ & + & $\mathrm{p}$ & ++ & 0 & - & $p$ & ++ \\
\hline
\end{tabular}

was always determined with the original host of the respective phage. The plates were incubated at the same temperature as the liquid cultures, however, with strain $\mathrm{A} 432$ parallel plates were also incubated at $25^{\circ} \mathrm{C}$ for cultures grown at $37^{\circ} \mathrm{C}$.

The results of these experiments are compiled in Table 5. Bacteria able to grow in SWB at $37^{\circ} \mathrm{C}$ generally propagate phages under this condition, although to varying degrees. An interesting exception is strain A432 which is unable to propagate phage A432/1 at $37^{\circ} \mathrm{C}$ in liquid or plate culture. This inability does not rest with the phage which is propagated in SWB at $37^{\circ} \mathrm{C}$ by strain $\mathrm{A} 335$.

In spite of the unusual temperature tolerance as well as of marked differences in salt requirements of some of the bacteria and phages, from the findings presented in Tables 4 and 5 it is concluded that all phage-host systems combined in cluster 14 are marine ones.

\section{DISCUSSION}

The main objective of this investigation was to enable correct interpretation of formerly observed sensitivity of bacteria to bacteriophages isolated from marine waters (Moebus \& Nattkemper, 1981) in terms of two possible types of reaction:. propagation of phages by bacteria or inhibition of bacteria by phage lysates. As revealed by spot testing 
of serially diluted lysates, the inhibition reaction is encountered in many phage-host systems of marine origin. According to the results of Moebus \& Nattkemper (1981) its strain specificity is as distinct as that of the lytic response to infection by bacteriophages. Therefore, inhibition and lytic reactions are assumed to be equally well suited to conclude on relationships between bacteria. This view is supported by the present findings with phage-host systems characterized by inhibition or lytic response depending on the incubation temperature.

Crude phage lysates as used in this investigation besides infective phage particles may contain defective ones as well as bacteriocins which also inhibit (kill) sensitive bacteria (Reeves, 1972). Therefore, from the present findings it cannot be concluded which type of agent(s) inhibited the bacteria. In preliminary experiments performed in liquid culture (at $25^{\circ} \mathrm{C}$ ) with several phage-host systems known to yield the inhibition reaction at $5^{\circ}, 15^{\circ}$, and $25^{\circ} \mathrm{C}$, it was always found that infective phage particles adsorbed to the bacterial cells tested. After $30 \mathrm{~min}$ the proportion of phage particles: cells which lost their ability to form plaques (on lawns of the phages' original hosts) and colonies, respectively, approximated a value close to the proportion of PFU : CFU adjusted at the beginning of the experiment (Moebus, unpublished data). From these observations one can, at least, conclude that infective phage particles were not a priori excluded from the processes causing cell inhibition. Inhibition by infective phage was demonstrated by Maiti (1978) who used purified lysates.

Maiti (1978) reported investigations with phage $\Phi 149$ which is propagated in Vibrio cholerae (classical) strain OGAWA 154 but kills $V$. cholerae (El Tor) strain MAK 757 without phage propagation. The ${ }^{32} \mathrm{P}$-labelled DNA of the phage was transferred into cells of both bacterial strains, however, in El Tor strain 757 infection resulted in an immediate reduction of metabolism whereas in strain OGAWA 154 metabolism decreased only after about $30 \mathrm{~min}$, i. e. at the end of the phage's latent period. From his results, Maiti (1978) concluded that the inactivation of El Tor strain 757 by phage $\Phi 149$ is due to damage of the cytoplasmic membrane which could not be repaired since the information of the phage DNA remained unexpressed.

Breakdown of the permeability barrier was also found with other bacteria which are killed by adsorbed phages without propagating them (Fields, 1969; see also Reeves, 1972 ; p. 79), and similar effects on the cell membrane are suggested in regard to the lethal affect of phage ghosts (Duckworth, 1970; Winkler \& Duckworth, 1971).

As for the present findings no information is available regarding the mechanism(s) causing cell inactivation. The same relates to plaques produced under certain temperature regimes which yielded no or only few progeny phages.

According to the findings of this investigation the importance of lysogenization of bacteria by temperate phages was second to inhibition in causing the turbid spots observed by Moebus \& Nattkemper (1981) in phage-host cross-reaction tests. Twentynine phage strains were identified as temperate ones which established lysogeny in 54 phage-host systems comprising 33 different bacterial strains. From the observation of homogeneously turbid plaques resembling those found with the original (lysogenizable) hosts of the temperate phages it is concluded that additional 55 phage-host systems produce turbid spots due to lysogenization of the bacteria.

Moebus \& Nattkemper (1981) also observed turbid spots seemingly caused by numerous tiny plaques. The present investigation revealed that such turbid spots 
occurred with phage-host systems mainly characterized by the inhibition reaction. The number of tiny plaques (diameter $0.2 \mathrm{~mm}$ or less) decreased rapidly with increasing dilution of the lysate in question reaching nil when no inhibition was detectable within the test area. With some of such phage-host systems phage propagation was observed in liquid culture.

Conspicuous differences in the sensitivity of bacteria isolated west of the Azores to phages derived from samples collected east of these islands, and vice versa, were reported by Moebus \& Nattkemper (1981, Fig. 1). In 164 "eastern" bacteria sensitivity to "western" phages was found 148 times, however, in 162 "western" bacteria sensitivity to "eastern" phages was observed only 52 times. Furthermore, sensitivity patterns to "western" phages were often found to be similar among "eastern" and "western" bacteria, whereas in regard to "eastern" phages such similarities between both groups of bacteria were almost absent. These findings were assumed to indicate genetic changes occurring in bacterial and bacteriophage populations while they are transported from west to east. This view is supported by some of the present results.

Taxonomic investigations of the bacteria comprising clusters 1 and 2 (Moebus \& Nattkemper, 1983) demonstrated close relationship on the genus level between the members of each of the 2 groups. The large number of different phage sensitivity patterns, however, indicates great genetic diversity among the bacteria (and bacteriophages) combined in both clusters. The occurrence of inhibition reaction instead of lytic response of bacteria to phages is certainly due to changes in the genetic information of bacteria and/or phages. Since inhibition is easily detected, this type of mutation(s) is of special value.

As can be seen from Figures 3 and 4 , with "western" phage-host systems it was found that the relative frequency of inhibition reactions, as compared with that of lytic responses, tends to increase with the distance between the stations where both parts of the systems were derived. This finding is all the more suggestive as the presentations in Figures 3 and 4 are based on a small number of phage-host systems. The fact that hydrographical parameters are not taken into consideration in Figures 3 and 4 is probably less important in regard to "western" systems since between the Bermudas and the Azores oceanic currents flowing north-eastward prevail. For these reasons it is assumed that the observations made with "western" systems cannot be explained as being mere accident. They rather reflect genetical changes in bacteria and phages, the chances of which occurrence increase with the time needed to transport the organisms from west to east.

In the "eastern" phage-host systems of cluster 1 (Figs 1 and 3), inhibition and lytic responses were found to almost equal degrees. This finding points to the possibility that "eastern" bacteria and phages are genetically more diverse than their counterparts in the western Atlantic. Based on the hypothesis assuming mutational changes of bacteria and phages during their transport from west to east one might be tempted to interpret the ubiquity of phage-host systems yielding the inhibition reaction by "accumulation" of such systems in the eastern Atlantic. However, the present results do not warrant such an interpretation. The 58 "east-west" systems available from cluster 1 provide no helpful information since most of them belong to the upper distance classes (Fig. 3). The same is true in regard to cluster 2. A large number of "east-west" systems isolated from samples taken in the transient zone between eastern and western Atlantic would be needed to 
interpret the remarkable differences observed between the "eastern" and "western" phage-host systems of cluster 1.

\section{LITERATURE CITED}

Blair, J. E. \& Williams, R. E. O., 1961. Phage typing of Staphylococci. - Bull. Wld Hlth Org. 24, $771-784$.

Duckworth, D, H., 1970. Biological activity of bacteriophage ghosts and "take-over" of host functions by bacteriophage. - Bact. Rev. 34, 344-363.

Fields, K. L., 1969. Comparison of the action of colicins E1 and K on Escherichia coli with the effect of abortive infection by virulent bacteriophages. - J. Bact. $97,78-82$.

Kasatiya, S. S. \& Nicolle, P., 1974. Phage typing. In: Handbook of microbiology. Ed. by A. I. Laskin \& H. A. Lechevallier. CRC Press, Cleveland, Ohio, 1, 632-650.

Maiti, M., 1978. Mode of action of bacteriophage $\Phi 149$ on cholera and El Tor Vibrios. - Can. J. Microbiol. 24, 1583-1589.

Moebus, K., 1980. A method for the detection of bacteriophages from ocean water. - Helgoländer Meeresunters. 34, 1-14.

Moebus, K. \& Nattkemper, H., 1981. Bacteriophage sensitivity patterns among bacteria isolated from marine waters. - Helgoländer Meeresunters. 34, 375-385.

Moebus, K. \& Nattkemper, H, 1983. Taxonomic investigations of bacteriophage sensitive bacteria isolated from marine waters. - Helgoländer Meeresunters. 36, 357-373

Reeves, P., 1972, The bacteriocins. Springer, Berlin, 142 pp.

Winkler, H. H. \& Duckworth, D. H., 1971. Metabolism of T4 bacteriophage ghost-infected cells; effect of bacteriophage and ghosts on the uptake of carbohydrates in Escherichia coli B. - J. Bact. 107, 259-267. 